\title{
Who Really Benefits from Mandatory Adoption of IFRS? A Closer Look at Preparers and Users of Financial Information
}

\author{
Michel Sayumwe ${ }^{1, *} \&$ Claude Francoeur ${ }^{2}$ \\ ${ }^{1}$ Université du Québec à Montréal, Montreal, Quebec, Canada \\ ${ }^{2}$ HEC Montréal, Montreal, Quebec, Canada \\ *Corresponding author: Université du Québec à Montréal, Montreal, Quebec, Canada. E-mail: \\ sayumwe.michel@uqam.ca
}

Received: March 9, 2017 Accepted: March 18, 2017 Published: March 25, 2017

doi:10.5296/rae.v9i1.10900 URL: https://doi.org/10.5296/rae.v9i1.10900

\begin{abstract}
Since 1 January 2005, the European Union (EU) has mandated implementation of International Financial Reporting Standards (IFRS) for preparation of consolidated financial statements for EU-listed firms. This paper analyzes the economic impact of mandatory adoption of IFRS on firms, investors, and creditors. Relying on the positive accounting theory, we study the economic impact of the new conceptual framework of financial information from IASB (2010), especially in paragraph OB2, where investors and creditors are designated as the main users of financial information, and QC 38, which assesses whether the benefits of financial information justify the costs associated with its production and use. Our sample is composed of 2,926 European firms that adopted IFRS in 2005. Results show that firm's cost of capital declines when comparing data before and after IFRS adoption. For creditors, our results suggest that credit rating improves after IFRS adoption. However, we do not notice any significant difference in the quality of accounting earnings for investors.

We also test if these results hold in the presence of asymmetric information, financial dependence and family ownership structure. Our results confirm the above trend. We conclude that the market anticipates the content of accounting data, and that mandatory adoption of IFRS has no impact on investors.
\end{abstract}

Keywords: economic impact, European Union, financial transparency, IASB Conceptual Framework, IFRS, positive accounting theory 


\section{Introduction}

The phenomenon of international accounting normalization interests many researchers in accounting. With mandatory adoption of IFRS in the European Union (EU) and other countries from 1 January 2005, some studies (e.g., Barth, Landsman and Lang ,2008) focus on the argument that IFRS improves the quality of financial reporting. Thus, the major difference between IFRS and various local accounting standards is the notion of financial transparency. According to the 2010 IASB Conceptual Framework, the goal of general financial reporting is to provide, about the presenting entity, useful information to current and potential investors, lenders, and other creditors for their decisions as providers of resources to the presenting entity. These decisions include purchase, sale, or holding of debt instruments or equity and making available loans or other forms of credit. We focus on paragraphs OB 2 and QC 38 of the Conceptual Framework.

The accounting literature shows that reducing the cost of capital, as international accounting standards-setters desire, following adoption of IFRS, is primarily an empirical question (Daske, Hail, Leuz and Verdi, 2008). Since mandatory adoption of IFRS on 1 January 2005 by EU member countries and other countries, some researchers have tested the empirical validity of this assertion. To date, the results of empirical tests seem torn between reduced and non-reduced capital costs. By separating cost of capital into its two components (cost of equity and cost of debt), some authors, such as (Kim and Shi,2007), suggest that cost of equity has decreased, while others, like (Cuijpers and Buijink,2005; Daske,2006), conclude that it has not. Regarding cost of debt, Kim and Shi (2007) argue that in countries that have adopted IFRS, firms observe lower interest rates, higher credit spreads, less restrictive credit clauses, and more interest from foreign lenders.

In the history of accounting, the greatest historical event in the advancement of international accounting standards is undoubtedly the adoption of Regulation (EC) no. 1606/2002 by the European Parliament and the Council of 19 July 2002 on the implementation of IFRS. The EC regulation requires all European listed firms to use IFRS to prepare their consolidated financial statements for financial periods beginning on or after 1 January 2005.

While the results of previous studies are generally limited with respect to the economic consequences of mandatory adoption of IFRS, our overall analysis raises a general hypothesis that there is no simultaneous economic benefit for preparers of financial information, investors, or creditors. To test this, we compare measures of economic benefit for preparers of financial information to analyze the statistical significance of differences between the period 2002 to 2004 (before adoption) and 2005 to 2007 (after adoption). In a second step, we analyze factors that explain the perceived benefits suggested by the new conceptual framework of the IASB through lower cost of capital for firms, better earnings quality, and improved credit rating. This analysis focuses on 2,926 firms in eight countries of the EU over six fiscal years from 2002 to 2007.

Thus, our purpose is to analyze the determinants of economic benefits of mandatory adoption of IFRS for firms, investors, and creditors. In so doing, our theoretical framework is that of 
positive accounting theory (Watts and Zimmerman, 1986). We make here an economic analysis of the production and use of financial information on the basis of government decisions to adopt IFRS. Indeed, the choice by governments to enact one set of standards rather than another is often seen as a response by politicians to stakeholder demands.

This study contributes to the accounting literature in that it takes as its starting point the new IASB Conceptual Framework, especially paragraphs OB 2 and QC 38, and positive accounting theory, which seeks to explain and predict the behavior of preparers and users of accounting information, for which the ultimate aim is to clarify the genesis of financial statements (Casta,2009). From the findings of (Ball, Robin, and Wu, 2003 Tendeloo and Vanstraelen, 2005), suggesting that the quality of information results from interaction between accounting standards and the economic environment, we focus on several key determinants, including information asymmetry, financial dependence, and family ownership structure. Previous studies have focused on voluntary adoption of IFRS. It's very important to accounting literature to understand the real benefits from the IFRS mandatory adoption by Governments around the word. In that context, can we really expect comparable benefits from the IFRS mandatory adoption for both preparers, investors and creditors? The IASB, while promoting its new accounting framework for the financial information, expects benefits from the IFRS mandatory adoption for both preparers, investors and creditors. To our knowledge, this paper is the accounting literature to analyze the economic impact of the IFRS mandatory adoption for the free stakeholders simultaneously. Our findings are in accordance with previous literature which predicts that both groups benefit from IFRS mandatory adoption. Surprisingly, the investors de not benefit from the use of IFRS which suggest that the capital market anticipates the content of accounting data, so that the new accounting referential has no economic impact on them.

This paper proceeds as follows. We set forth the theoretical framework of the International Accounting Referential (Section 2), a literature review (Section 3), and research hypotheses (Section 4). We then describe our methodology (Section 5) and discuss our results (Section 6). We conclude with a general discussion, the limitations of the study, and proposals for future research (Section 7).

\section{Theoretical Framework behind IFRS}

In the context of this paper, we rely primarily on positive accounting theory (Watts and Zimmerman, 1986) to explain the simultaneous presence of economic benefits generated by mandatory adoption of IFRS.

\subsection{Positive Accounting Theory}

The positive theory of accounting consists of two components: the political contractual theory of accounting, and the information content of accounting data.

Following (Ball and Brown, 1968; Beaver, 1968; Watts and Zimmerman, 1986) proposed a new stream of literature in pursuit of a true accounting theory. Such theory should be able to 
explain and predict accounting practices in a given jurisdiction and at a given time. The authors begin by noting that, for many years, various stakeholders spent a lot of resources to influence accounting regulations, in the United States and elsewhere, taking advantage of the normal process of standards setting, including the survey presentation stage. To understand this activity, an accounting theory should explain the source of the pressures that a firm can put on the process of accounting standards setting. During this process, one of the most important actors is management in organizations that will use any standards. Gordon (1964) was the first to suggest that managers select accounting standards that maximize their own utility.

The positive accounting theory, which aims to explain and predict the behavior of managers and standards-setters in the choice of accounting methods, shows that lobbying plays a critical role with respect to due process in accounting standards setting.

\subsection{New Conceptual Framework for Financial Reporting}

The objective of convergence of national accounting standards and IFRS accounting standards setting led the world to develop a new, joint conceptual framework between the IASB and the FASB. In the first chapter of the IASB Conceptual Framework for Financial Reporting (2010), the objective of financial reporting for general use is to provide financial information about an entity that is useful to current investors and potential lenders and other creditors, in making decisions about allocating resources to the entity (paragraph OB2). On the other hand, paragraph QC 38 states that application of the cost constraint leads to assessment of whether it is likely that the benefits of the information justify the costs of its production and use.

\section{Literature Review and Prior Empirical Evidence}

In this section, we review the literature on the concept of quality of accounting standards and the analysis of economic benefits of mandatory adoption of IFRS for businesses and investors.

\subsection{IFRS Quality and Financial Transparency}

The issue of international financial reporting standards is closely related to perceived quality level, compared with national accounting standards. It is therefore useful to understand the notion of quality of information and the characteristics of such information as IFRS fair value accounting data.

The notion of quality of financial information is not defined as such. However, the IASB Conceptual Framework introduces the concept of "qualitative characteristics," defined as those qualities that make financial information useful.

For Disle and Noël (2007), adoption of IFRS is accompanied by major changes: a shift from a legal approach to an economic approach toward accounting, and a shift from historical cost to fair value accounting. The question of the quality of accounting standards is of great 
importance, since its main users question information content with respect to allocation decisions for economic resources that they must take. To address this question, (Barth, Landsman and Lang ,2008) begin by defining what is high quality accounting information. According to these authors, the characteristics of such information are based on earnings management and relevance value. High quality information must generate a net profit with little use of earnings management. This manifests itself as follows: a low frequency of low positive net results and a weak negative correlation between accruals and cash flow. For these authors, firms that have adopted IFRS are characterized by low results smoothing, low earnings management, quick recognition of losses and high correlation between accounting data and stock prices and stock returns. As part of the production and use of financial information under IFRS, Hope, Jin and Kang, (2006) assume that for the issuer of financial statements, the following benefits are expected: lower cost of capital, increasing firm value, increasing volume of transactions, and improving firm reputation. These authors add that transaction costs are low for preparers, as they adhere to a single set of accounting standards, regardless of the stock market in which the undertakings concerned are listed. For users of financial statements, the authors assume that minority shareholders, foreign investors, and governments benefit from lower cost of capital. In addition, there is a savings of time and energy in the interpretation of financial statements using a single set of accounting standards, due, in part, to the fact that comparison is facilitated.

Barth and Schipper (2008) propose defining financial transparency as the extent to which financial reporting by an entity reveals the underlying economic reality and the extent to which the reporting is understandable by users. In principle, transparency in financial reporting may result in lower cost of capital due to reduced information risk. Thus, transparency is a characteristic sought by users of financial information. It should also be considered, according to these authors, the risk the entity faces, so that financial transparency includes risks and how management makes decisions. In some cases, interested parties may be more numerous than the traditional users of financial information. Thus, according to Transparency International, transparency of information allows administrative decision makers, economic operators, and charity workers to know not only the facts and basic information, but also mechanisms and procedures.

\subsection{Analysis of Economic Benefits of IFRS Mandatory Adoption for Businesses}

Accounting produces information on the process of creating and distributing value, and its implementation is justified only when the benefits are higher than the costs (Charreaux and Desbrières, 1998). These induced benefits can be transformed into lower cost of capital for the issuer of the financial information. However, cost of capital is the main tool for assessing important business decisions on investment, both in terms of amount invested and the quality of the investments (Habib, 2006).

In the same vein, Francis, Khurana and Pereira (2005) was among the first to analyze simultaneously the two components of cost of capital, i.e., cost of debt and cost of equity capital in the context of a correlation analysis with disclosure incentives for firms. The study concludes that firms with a strategic policy of disclosure are able to reduce both cost of debt 
and equity cost, taking into account differences in legal protection for investors and differences in financial systems.

Overall, and based on a content analysis of some reports, Guay, Kothari and Shu (2011) note that cost of capital decreases if disclosure is positive and increases in the opposite case. This effect seems more pronounced for disclosure in the financial press compared to one made by financial analysts.

To analyze the possible link between cost of capital and transparency in results, Barth, Konchitechki and Landsman (2011) aim to determine whether firms with results that are more transparent - that is to say, income that is more representative of changes in the economic situation of the entity-have lower cost of capital. According to these authors, the more transparent are the results, the lower is information asymmetry. They conclude that firms that show more transparency have lower cost of capital, because transparent accounting results reflect changes in economic conditions in a way that is understandable by investors.

\subsection{Analysis of Economic Benefits of IFRS Mandatory Adoption for Investors}

In the accounting literature, financial analysts are always considered as appointed representatives of investors. This perspective does not allow researchers to capture the overall behavior of investors in their diversity. The benefits for investors following mandatory adoption of IFRS may bring about a better quality of accounting income, low earnings management, or increased relevance of accounting income. To understand the impact of mandatory IFRS adoption on information content, Beuselinck, Joos, Khurana and Van der Meulen (2010) study the impact of mandatory adoption of IFRS on the opacity of firms, and contributes to improving information content as measured by the synchronicity of stock returns with earnings per share. The study concludes that adoption of IFRS, reducing the opacity of firms, helps to improve the information content of financial statements in relation to stock price from 2005, compared to the period before mandatory adoption of IFRS.

Florou and Pope (2012) analyze the impact of mandatory introduction of IFRS decisions on resource allocation by institutional investors. Based on a sample of more than 144,000 institutional investors making transactions in nearly 4,000 firms in 24 countries, these authors note a large change in acquisition of new shares during the year of mandatory adoption of IFRS and the following year. It should be noted, however, that such changes occur only in countries with high legal protections, low levels of corruption, and weak governance. These research findings suggest ultimately that many investors expect that mandatory use of IFRS lowers cost of capital.

Improving the quality of financial reporting under IFRS is also addressed in Iatridis (2010), whose results suggest that mandatory adoption of international standards reduces the practice of earnings management. In addition, it decreases information asymmetry, with greater transparency and greater quality of accounting information. Tucker and Zarowin (2006) raise the question of whether income smoothing improves the quality of financial reporting. The authors use Compustat data between 1993 and 2000 and set forth two hypotheses. The first is that income smoothing improves information content if managers use caution in their 
assessment of future results. The second is that the smoothing results make managers more aggressive, leading them to intentionally distort forecast data. The study concludes that change in the market prices of shares of firms smoothing the most contains more information than firms that engage in less smoothing.

Ownership structure may also influence the information content of the reported earnings. Thus, in the context of Polish enterprises, Korczak and Korczak (2009) integrate the environment of corporate governance to analyze its effect on the expropriation and reporting of financial information. Results show that ownership oncentration has a positive effect on the information content of reported earnings.

\subsection{Analysis of Economic Benefits of IFRS Mandatory Adoption for Creditors}

Creditors are important stakeholders in businesses, and any analysis of economic consequences of mandatory adoption of IFRS should take them into consideration (Wu and Zhang, 2009). Indeed, in their study on law and finance, La Porta, Lopez-de-Silanes, Shleifer and Visny (1998) consider that, on average, the banking sector and other private debt bonds represent $59 \%$ of gross national product. Some studies therefore focus on the contract role of accounting information in particular with respect to bank loans, and whether this information is prepared according to international financial reporting standards. For example, Kosi, Pope and Florou (2012) analyze the relevance of accounting information under IFRS for business credit rating. To determine the credit rating of a firm, analysts make a comprehensive survey of its financial situation and take into account both qualitative aspects (related to business risk) and quantitative ones (related to financial risk). Overall, the elements of business risk taken into account are: political risk of the country, characteristics of the industry, competitive position, profitability, and comparative data within the sector. Regarding financial risk, rating agencies take into account governance of the firm, financial strategy, accounting information, availability of liquidity, and capital structure. Rating agencies generally agree that financial statements are the first source of information on which they base issuance of credit. Usually, credit relevance is seen as the correlation between accounting information and the expectations of creditors with respect to future liquidity generated by the firm's operations. Overall credit score improves when comparing the statistical results before and after mandatory use of IFRS for the same firms.

Ball, Robin and Sadka (2008) focus on how financial communication is influenced by the capital market or bank debt. Building on the famous (Ball and Brown, 1968), these authors propose that debt markets create great demand for financial communication. The authors thus use a sample of 22 countries to determine that debt markets are correlated with important properties of financial communication. There are several differences between the two main categories of users of financial information. First, debt markets, more than equity markets, require quick posting of information to financial statements, because many debt contracts specifically refer to them. With regard to portfolio management, the more investors are diversified, the less they are interested in the correlation between earnings and stock performance. For creditors, on the other hand, the notion of diversification does not apply, since debt contracts are written with reference to the individual data of each borrower. Finally, 
a large difference in the level of demand for financial communication appears between debt and equity when there is a change in the value of the firm and its debt. Results suggest that rapid financial communications is a costly activity and its amount should depend on demand, for example, on the size of the stock market. Similarly, the speed of accounting for profits and losses is not correlated to the size of the stock market, while it is correlated with the size of the debt market. These results are consistent with predictions for the contractual role of accounting (Watts and Zimmerman, 1986).

Addressing the consequences of ratings by the credit agencies, Tang (2009) uses data from Moody's to analyze the effect of firm credit ratings on their subsequent borrowing costs. The study is based on a sample of 266 firms in 1982; these firms make little investments and hold a lot of cash. Thus, following a periodic update of information on credit quality, investors are in a position to better assess the creditworthiness of firms, so that when credit quality increases, firms benefit from better financing at lower cost and a greater access to debt financing. The opposite happens when a firm's credit rating is lowered.

Creditors appear to stand out from shareholders with regard to their information needs. Peek, Cuijpers and Bwijink (2009) compare information needs between shareholders and creditors in listed and private firms. Based on a sample of 13 European countries, the results suggest that a difference in quick application of information between public and private firms is not correlated with the degree of legal protection of investors. On the other hand, such difference is positively correlated with the degree of legal protection of creditors. It should be noted here that creditors of private firms have lower demand for accounting information than creditors of public firms, since private firms are usually engaged in long-term business relationships, allowing them access to other types of information. Thus, these results support the idea that agency problems between creditors and investors are more pronounced in private enterprises.

\section{Research hypotheses}

We build on the positive accounting theory (Watts and Zimmerman, 1968) to test a set of four research hypotheses. The first (H1) is a general assumption, while the other three center, respectively, on the presence of certain characteristics of firms, namely information asymmetry (H2), financial dependence (H3), and family ownership structure (H4).

\subsection{General Hypothesis of Economic Consequences of Mandatory IFRS Adoption}

Our research question focuses on identification of the determinants of economic benefits of mandatory adoption of IFRS. As a prerequisite to this question, H1 concerns the existence of these benefits. As described in the literature, three trends emerge.

Some authors, such as (Leuz,2003; Barth, Landsman and Lang; 2008; Liu, Yao, Hu and Liu,2011), estimate as advantageous the mandatory adoption of IFRS for all stakeholders (preparers and users of financial information), for several reasons. According to these authors, mandatory IFRS adoption increases information content, which leads to greater synchronicity between accounting and market data. In the same vein, some authors, such as (Ashbaugh, 
Pincus,2001; Hope, Jin and kang, 2006), explore arguments related to ease of production of information, communication, and exploitation by various actors. International financial reporting standards lower the cost of information, saving time and energy, and lower cost of capital, thereby facilitating greater mobility of capital across the world.

Other authors reach a less-clear conclusion, finding that the merits extolled are the result of private initiatives at the enterprise level rather than adoption of IFRS, which is in some cases purely a matter of labels (Daske, Hail, Leuz and Verdi,2012). They point out that the economic benefits identified are seen in countries with less stringent accounting standards and in firms listed on multiple stock exchanges, but much less so in countries where investors already enjoy high legal protection. The latest trend in the literature includes such authors as (Ball, Robin and Wu; e2003; Gao 2010; Atwood, Drake, Myers and Myers, 2011), who are rather against the idea that IFRS is superior to local standards. According to these authors, the quality of IFRS remains dependent on political and economic factors; the standards themselves do not increase the predictive ability of financial statements regarding the availability of future cash flows. The literature suggests that it is even possible to observe a positive relationship between disclosure quality and cost of capital regardless of the accounting standards used.

Apart from the fact that the economic benefits of mandatory adoption of IFRS are mitigated, we cannot ignore the problem, because the cost-benefit analysis conventionally used for such problems cannot be applied due to the difficulty or impossibility of quantifying the effects of an accounting standard. However, the ultimate goal is to determine whether it is worth the cost of adopting IFRS, i.e., whether the benefits to all parties exceed their costs.

Considering the controversy in the accounting literature over expected economic benefits following mandatory adoption of IFRS, we formulate H1 as follows:

\section{H1: There are no economic benefits to the main preparers or users of financial information following the mandatory adoption of IFRS.}

\subsection{Hypothesis of Information Asymmetry}

Contrary to H1, which is general in scope, H2 checks whether IFRS at least provides economic benefits in limited circumstances, specifically in firms marked by the phenomenon of information asymmetry.

On a theoretical level, the basic idea of Gordon (1964) that managers choose and support (through lobbies) accounting standards that maximize their own utility is weakened by invoking the conflicts of interest between managers and shareholders. Indeed, the former have more information on the financial health of the accounting entity but remain agents of shareholders. This uncertainty about the duration of their mandate, coupled with the possibility of voluntary departures for other opportunities, causes leaders to advocate for short-term projects, in opposition to those shareholders who prefer long-term projects. These conflicts of interest, which are due largely to information asymmetry, are even more evident between managers and creditors. This problem of information asymmetry is damaging to all 
stakeholders. Faced with the problem of divergence of interests even leading to the use of lobbying by actors who are not equally informed, the question is whether there is a relationship between mandatory adoption of IFRS and the benefits to each party.

According to the empirical literature (Diamond and Verrecchia, 1991; Tucker and Zarowin, 2006; Barth, Landsman and Lang, 2008; Ivashima, 2009; Beneish, Miller and Yohn, 2010), mandatory adoption of IFRS contributes precisely to mitigating this principal-agent problem. Indeed, the application of IFRS lowers the possibility of manipulation of accounting information, and increases the degree of harmonization, transparency, and good disclosure, making public otherwise private information. Consequently, this transparency increases the ability of creditors and investors to monitor and control their costs. In return, the firm is able to diversify its funding sources (including access to equity financing) and its cost of capital.

Because mandatory adoption of IFRS reduces information asymmetry and creates a good business climate among the parties, we formulate $\mathrm{H} 2$ as follows:

H2: The economic benefits derived by the main preparers and users of financial information are positively correlated with the mandatory adoption of IFRS in firms with high information asymmetry.

\subsection{Hypothesis of Financial Dependence}

Our third hypothesis helps to verify whether mandatory adoption of IFRS has an impact on firms with high financial dependence.

From a theoretical point of view, the theory of regulation (which is one of the main sources of the positive accounting theory) suggests that the drafting of debt or remuneration contracts avoids or manages conflicts between firm stakeholders. On one hand, the firm needs capital to fund its operations, and on the other, investors and creditors should be reassured by the financial situation of the firm. Mandatory adoption of IFRS facilitates greater drafting of contracts, including those for funding, by increasing the degree of information transparency and timeliness of disclosure. Use of IFRS increases the credit rating of firms that apply them, which benefit as a result of ease of access to more diversified funding sources with relatively low cost.

The literature also raises an indirect positive effect from IFRS related to the problem of information asymmetry already discussed. This situation is more pronounced in private enterprises than in publicly traded firms (Peek, Cuijpers and Bwijink,2009), reducing the problem, and consequently improving IFRS economic benefits to stakeholders in this type of business. Kim, Tsui and Yi (2011) generate empirical evidence of some of these expected effects, including lower capital cost and ease of access to finance.

The following research hypothesis is based on the notion of dependence on external financing, or financial dependence, defined by (Rajan and Zingales,1998) as the ratio of the amount of debt relative to capital expenditures. Thus, from the literature, we formulate $\mathrm{H} 3$ as follows:

H3: The economic benefits derived by the main preparers and users of financial 


\section{information are positively correlated to the mandatory adoption of IFRS in firms experiencing strong financial dependence.}

\subsection{Hypothesis of Family Ownership Structure}

The final hypothesis aims to identify the relationship between use of IFRS and the type of ownership structure in a given firm. More specifically, the literature leads us to assume some positive correlation between mandatory adoption of IFRS and economic benefits experienced simultaneously by firms and investors in the case of family businesses. In general, these firms suffer from many problems (Fan and Wong, 2002; Zhao and Millet-Reyes, 2007; Korczak and Korczak, 2009). Among these are the agency problem, low quality of disclosure, weak protection of minority shareholders, and manipulation of accounting results. Conflicts of interest that arise in this context often lead to the phenomenon of rooting or expropriation of minority shareholders by the dominant shareholder. Mandatory adoption of IFRS is therefore seen as one solution to many of the problems mentioned above. It is generally accepted that IFRS, because it requires firm management to provide a lot of information in the form of notes to the financial statements, allows mitigation of information asymmetry between firms and the main users of financial information. The quality of accounting information so improved facilitates drafting of contracts, such as compensation and debt contracts. Such contracts ensure more stability to related entities and reassure external partners. Mandatory adoption of IFRS acts directly on the system of financial reporting, which is linked to the legal system of governance, which in turn influences the types of ownership structure encountered.

As empirical evidence, Ali,Tai-Yuan and Suresh (2007) find that reported earnings after mandatory adoption of IFRS are better in family businesses, and they are likely to issue alerts in case of bad news. While it is true that we do not assume a relationship between mandatory adoption of IFRS and economic benefits simultaneously recorded in other types of ownership, we must not underestimate the importance of family owned businesses in relation to their prevalence in the European economy.

In view of the importance of family owned businesses and the expected impact of mandatory adoption of IFRS, we formulate H4 as follows:

H4: The economic benefits derived by the preparers and main users of financial information are positively correlated with the mandatory adoption of IFRS in family owned firms.

\section{Sample and Methodology}

\subsection{Sample Selection}

We first list all publicly traded firms whose total assets exceed 10 million euros at the end of the 2002 fiscal period. We then exclude all countries who have allowed voluntary adoption of IFRS prior to January 1 2005, namely Germany, Greece, Belgium, Luxembourg, Portugal, 
Austria, Finland, Cyprus, Malta, Estonia, Hungary, Latvia, Lithuania, Poland, and the Czech Republic.

In a third stage, we exclude all financial corporations and all firms for which we were unable to find the required data in the Worldscope database. Our final sample is composed of 2,926 firms operating in eight countries and distributed in nine economic sectors, as shown in Table 1 .

Table 1. Distribution of Sample Firms by Economic Sector and Country

\begin{tabular}{|c|c|c|c|c|c|c|c|c|c|c|}
\hline & Country code & 1 & 2 & 3 & 4 & 5 & 6 & 7 & 8 & \\
\hline 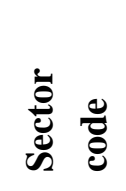 & & 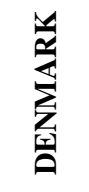 & $\frac{z}{\bar{s}}$ & 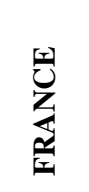 & 彥 & 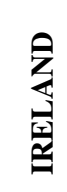 & 离 & 正 & 空 & 產 \\
\hline 1 & Agriculture, forestry and fishing & & 7 & 4 & 1 & 1 & & 6 & 7 & 26 \\
\hline 2 & Mining & 3 & 16 & 32 & 10 & 5 & 12 & 73 & 15 & 166 \\
\hline 3 & Construction industries & 21 & 16 & 45 & 13 & 6 & 27 & 93 & 15 & 236 \\
\hline 4 & Manufacturing & 38 & 25 & 145 & 49 & 5 & 62 & 214 & 75 & 613 \\
\hline 5 & Transportation and utilities & 11 & 20 & 75 & 14 & 4 & 44 & 140 & 14 & 322 \\
\hline 6 & Wholesale & 20 & 16 & 79 & 20 & 8 & 11 & 101 & 16 & 271 \\
\hline 7 & Retail & 8 & 10 & 86 & 8 & 2 & 30 & 106 & 17 & 267 \\
\hline 8 & Real estate & 13 & 21 & 56 & 17 & 1 & 12 & 86 & 18 & 224 \\
\hline \multirow[t]{2}{*}{9} & Services & 20 & 14 & 179 & 32 & 20 & 39 & 428 & 69 & 801 \\
\hline & TOTAL & 134 & 145 & 701 & 164 & 52 & 237 & 1247 & 246 & 2926 \\
\hline
\end{tabular}

We distinguish the pre-adoption ( 3 years) from the post-adoption ( 3 years) period. This allows us, as a first step, to compare and analyze the economic benefits of mandatory adoption of IFRS for the main preparers and users of financial information. In a second step, we analyze the determinants of these economic benefits for firms, investors, and creditors.

\subsection{Empirical Model and Measurement of Variables}

The main empirical model relates the economic benefits of transparency of financial information (EBTFI), as the dependent variable, to a set of explanatory variables. To capture the effect of various firm characteristics, we include interactions between the respective mandatory adoption of IFRS and variables of interest namely: information asymmetry (ASYM*IFRS), financial dependence (IFRS*FIN_DEPEND), and family ownership (IFRS * FAMILY). The model is as follows:

$$
\begin{aligned}
& \text { EBTFI }_{\mathrm{it}}=\beta_{0}+\beta_{1} \text { IFRS }_{\mathrm{t}}+\beta_{2} \text { ASYM }_{\mathrm{it}}+\beta_{3} \text { FIN_DEPEND }_{\mathrm{it}}+\beta_{4} \text { FAMILY }_{\mathrm{it}}++\beta_{5} \text { IFRS }_{\mathrm{t}} \text { ASYM }_{\mathrm{it}}+ \\
& \beta_{6} \text { IFRS }_{\mathrm{t}}^{*} \text { FIN_DEPEND }_{\mathrm{it}}+\beta_{7} \text { IFRS }_{\mathrm{t}}^{*} \text { FAMILY }_{\mathrm{it}}+\beta 8 \text { SEPARATION }_{\mathrm{it}}+\beta_{9} \text { CAPITALIZATION }_{\mathrm{it}}+ \\
& \beta_{10} \text { CORRUPTION }_{\mathrm{it}}+\beta_{11} \text { PROTECTION }_{\mathrm{it}}+\beta_{12} \text { TAXATION }_{\mathrm{it}}+\beta_{13} \text { US_COTATION }_{\mathrm{it}}+ \\
& \beta_{14} \text { COUNTRY }_{\mathrm{it}}+\beta_{15} \text { INDUSTRY }_{\mathrm{it}}+\varepsilon
\end{aligned}
$$


We set forth in Table 2 the definitions of all variables.

Table 2. Definition of Dependent, Independent, and Control Variables

\begin{tabular}{|c|c|}
\hline VARIABLE & Definition and measurement \\
\hline ASYM & $\begin{array}{l}\text { Level of information asymmetry. Following Degryse and Jong }(2006)^{1} \text {, we classify sample } \\
\text { firms into two categories according to whether their Tobin's Q is greater than } 1 \text { (codified } \\
\text { 1) or not (codified 0). }\end{array}$ \\
\hline CAPITALIZATION & Market value of the firm. \\
\hline CORRUPTION & $\begin{array}{l}\text { Level of corruption in a given country. The data are available on the website of } \\
\text { Transparency International. }\end{array}$ \\
\hline EBTFI & $\begin{array}{l}\text { Economic benefits of transparency of financial information measured by cost of capital for } \\
\text { firms and by accounting quality for investors. }\end{array}$ \\
\hline FAMILY & $\begin{array}{l}\text { Binary variable giving the identity of the shareholder: } 1 \text { for family, or } 0 \text { for all other types } \\
\text { of structures (main shareholder is an institution, state-owned firm dispersed, etc.). }\end{array}$ \\
\hline FIN_DEPEND & $\begin{array}{l}\text { Level of dependence on bank financing. The data are calculated according to Rajan and } \\
\text { Zingales (1998). }\end{array}$ \\
\hline IFRS & $\begin{array}{l}\text { Mandatory adoption of IFRS. Dichotomic codification is used: } 0 \text { for the financial periods } \\
2002,2003 \text {, and 2004, and } 1 \text { for the financial periods 2005, 2006, and } 2007 \text {. }\end{array}$ \\
\hline IFRS*ASYM & $\begin{array}{l}\text { Interaction between mandatory adoption of IFRS and presence of information asymmetry } \\
\text { in the firm. }\end{array}$ \\
\hline IFRS*FAMILY & Interaction between mandatory adoption of IFRS and family ownership structure \\
\hline IFRS*FIN_DEPEND & $\begin{array}{l}\text { Interaction between mandatory adoption of IFRS and presence of financial dependence in } \\
\text { the firm. }\end{array}$ \\
\hline INDUSTRY & Industrial sector. \\
\hline PROTECTION & $\begin{array}{l}\text { Binary variable indicating the type of legal protection in a country: common law (denoted } \\
\text { 1) or code law (denoted } 0 \text { ). }\end{array}$ \\
\hline RATING & Rating ranking of the firm \\
\hline SEPARATION & $\begin{array}{l}\text { Identifies the presence (coded } 1) \text { or not (coded } 0) \text { of the separation of voting rights and } \\
\text { property rights. }\end{array}$ \\
\hline TAXATION & $\begin{array}{l}\text { Binary variable indicating type of consistency between accounting and taxation in a given } \\
\text { country, denoted } 1 \text { if the accounting profit differs from profit tax, } 0 \text { in the opposite case. }\end{array}$ \\
\hline US_COTATION & $\begin{array}{l}\text { Binary variable reflecting the fact that a firm is listed (denoted } 1 \text { ) or not on a U.S. stock } \\
\text { exchange (denoted } 0 \text { ). }\end{array}$ \\
\hline QUALITY & $\begin{array}{l}\text { Quality of the result set as the response factor of future results as used by Tucker and } \\
\text { Zarowin (2006). }\end{array}$ \\
\hline
\end{tabular}

${ }^{1}$ These authors base their conclusions on the findings of Hayashi (1982) and Vogt (1994) that firms with Q greater than 1 face problems of asymmetric information. 


\subsection{Description and measurement of the dependent variable}

Our first proxy for EBTFI is the cost of capital (COST_CAPITAL) for preparers of financial information. By definition, cost of capital is the weighted average of the cost of equity capital and the cost of debt. However, in this research, we use only the cost of equity component. Indeed, apart from a few cases, such as (Francis, khurana and Pereira, 2005), most previous studies consider only the cost of equity to measure overall cost of capital, e.g. (Botosan and Plumlee, 2002; Daske, Hail, Leuz and Verdi, 2008; Gao, 2010; Guay, Kothari and Shu, 2011).

We use the target price method to measure the benefits to preparers of financial information.

The formula used is as follows:

$\mathrm{P}_{\mathrm{o}}=\Sigma\left(1+\mathrm{r}_{\mathrm{DIV}}\right)^{-\mathrm{t}}\left(\mathrm{dps}_{\mathrm{t}}\right)+\left(1+\mathrm{r}_{\mathrm{DIV}}\right)^{-5}\left(\mathrm{P}_{5}\right)$

Where,

\begin{tabular}{ll}
\hline $\mathrm{P}_{\mathrm{o}}$ & Stock price at time $\mathrm{t}_{0}$ \\
$\mathrm{r}_{\mathrm{DIV}}$ & Cost of equity \\
$\mathrm{dps}_{\mathrm{t}}$ & Dividend per share for the current year \\
$\mathrm{P}_{5}$ & Stock prices in the fifth year \\
\hline
\end{tabular}

To estimate the target price, we collect basic information from the Worldscope database. After calculating cost of equity by derivation in the above formula for all firms in the sample, we replace EFBTI by the cost of capital (COST-CAPITAL) in the model above to test EBTFI for preparers of financial information is written as follows:

Accounting information is very useful for investors since it constitutes an important basis for decision making. To measure the economic benefits for investors following mandatory adoption of IFRS, the general trend in the literature is to emphasize the concept of quality of earnings. In this research, we choose to use the Future Earnings Response Coefficient (FERC) approach (Tucker and Zarowin, 2006) to measure EBFTI for investors. Those authors illustrate quite well the relationship between (FERC) and the information content of accounting earnings. The proxy used in this study is based on the conceptual framework of (Collins, Kothari, Shanken and Sloan, 1994). According to these authors, when a firm reports its results it has private information about future results. Since, under the market efficiency hypothesis, all new information is reflected in the change in stock prices, it is fair to conclude that this variation in stock price captures the change in investor expectations with respect to future accounting results. The strength of this relationship is captured by the response factor to future results. The strength of this relationship is captured by the response factor of future results.

The model of (Collins, Kothari, Shanken and Sloan(1994)used here is as follows: 
$\mathrm{R}_{\mathrm{t}}=\mathrm{b}_{0}+\mathrm{b}_{1} \mathrm{X}_{\mathrm{t}-1}+\mathrm{b}_{2} \mathrm{X}_{\mathrm{t}}+\mathrm{b}_{3} \mathrm{X}_{\mathrm{t} 3}+\mathrm{b}_{4} \mathrm{R}_{\mathrm{t} 3}+\varepsilon_{\mathrm{t}}$

The above variables are defined as follows:

$\mathrm{Rt}=$ annual stock return $=(\mathrm{Pt}+1-\mathrm{Pt}) / \mathrm{Pt}$

$\mathrm{Xt}-1$ = earnings per share in year $\mathrm{t}-1$ divided by the stock price at the beginning of year $\mathrm{t}$.

$\mathrm{Xt}=$ earnings per share in year $\mathrm{t}$ divided by the stock price at the beginning of year $\mathrm{t}$.

$\mathrm{Xt} 3=$ Sum of earnings per share in year $\mathrm{t}+1$ to $\mathrm{t}+3$ divided by the stock price at the beginning of year $\mathrm{t}$.

Rt3 $=$ Sum of stock returns for years $t+1$ to $t+3$.

Here, the basic information is derived from Wordscope. Once the b3 coefficient is calculated, we integrate the second empirical model for investors. Thus, the higher is the Future Earnings Response Coefficient, the more it explains a better quality of accounting information.

In this second model, we replace EBTFI with QUALITY, which represents the quality of accounting income, an economic advantage for investors.

The third empirical model uses the firm's credit rating (RATING)as proxy for EBFTI for creditors. which represents creditors' confidence level regarding firms' financial position. The RATING variable is collected from the database Bureau Van Dijk.

\subsection{Control Variables}

The CAPITALIZATION control variable is chosen in reference to the study of (Botosan and Plumlee, 2002) and is a proxy for firm's size. The use of size as a control variable is justified by the fact that larger firms generally disclose much information because it gives them many advantages.

In 1998, La Porta,Lopez-de-Silanes, Shleifer and Vishny have concluded that there is a fundamental difference in the level of legal protection for investors depending on whether the country is a common law tradition (high protection) or code law (low protection). We therefore need to control for the PROTECTION variable in our study.

The trend of reconciliation between accounting rules and tax rules is considered as a factor that may influence the quality of financial reporting (Ali and Hwang, 2000). To capture the harmonization of tax and accounting in a given country, we introduce the TAXATION control variable.

The difference in the business environment can be represented by the level of corruption and its potential effect on the financial information (Ball, 2001). Specifically, the author argues that any comprehensive analysis on the accounting standards should be situated in the context of financial market communication and political environment, including the level of corruption. We then introduce the CORRUPTION control variable in our paper.

SEPARATION variable is interesting to control for in the context of our research because it 
comes to refine the impact of family ownership structure on the economic benefits of the transparency of financial reporting. This variable distinguishes effect of firms identified as family type, which are characterized by the separation of ownership and voting rights. This kind of business is different from other family businesses because they are characterized by low market value (Claessens,Djankov, Fan and Lang, 2002; King and Santor, 2007).

As IFRS are especially characterized by high level of transparency, mandatory adoption by European firms would influence for firms less transparent. Moreover, Ashbaugh (2001) suggests that companies listed on several stock exchanges are very willing to voluntarily adopt IFRS. We specifically control for European firms listed on the U.S. Stock Exchanges by the US COTATION variable.

\subsection{Correlation Analysis of Variables of the Three Empirical Models}

Table 3 addresses the possible existence of a collinearity problem in the four models. By calculating the linear correlation coefficients between the independent variables taken two by two, we find no particular high coefficient of correlation which would indicate possible collinearity problems.

Table 3. Correlation matrix of variables of the empirical model

\begin{tabular}{|c|c|c|c|c|c|c|c|c|c|c|c|c|c|c|c|c|}
\hline & & 1 & 2 & 3 & 4 & 5 & 6 & 7 & 8 & 9 & 10 & 11 & 12 & 13 & 14 & 15 \\
\hline 1 & COST_CAPITAL & & & & & & & & & & & & & & & \\
\hline 2 & QUALITY & -0.06 & & & & & & & & & & & & & & \\
\hline 3 & RATING & -0.16 & 0.13 & & & & & & & & & & & & & \\
\hline 4 & IFRS & -0.06 & 0.05 & -0.05 & & & & & & & & & & & & \\
\hline 5 & IFR*ASYM & -0.09 & 0.05 & -0.13 & 0.73 & & & & & & & & & & & \\
\hline 6 & IFRS*FIN_DEPEND & 0.08 & -0.04 & 0.14 & -0.3 & -0.17 & & & & & & & & & & \\
\hline 7 & IFRS*FAMILY & -0.09 & -0.02 & 0.05 & 0.27 & 0.13 & -0.12 & & & & & & & & & \\
\hline 8 & ASYM & -0.17 & 0.01 & -0.2 & 0.16 & 0.62 & 0.01 & -0.34 & & & & & & & & \\
\hline 9 & FIN_DEPEND & 0.05 & 0.03 & 0.08 & 0.08 & 0.07 & 0.13 & 0.02 & -0.05 & & & & & & & \\
\hline 10 & FAMILY & -0.12 & -0.04 & 0.06 & -0.06 & -0.08 & 0 & 0.52 & -0.16 & 0.02 & & & & & & \\
\hline 11 & SEPARATION & -0.13 & 0.16 & 0.05 & 0.04 & -0.05 & 0 & -0.02 & -0.08 & 0.06 & 0.1 & & & & & \\
\hline 12 & PROTECTION & -0.11 & 0.01 & 0.12 & -0.07 & -0.08 & 0.04 & -0.06 & -0.08 & 0.07 & 0.11 & -0.15 & & & & \\
\hline 13 & TAXATION & 0.4 & -0.08 & 0.06 & -0.06 & -0.07 & 0.2 & -0.07 & -0.09 & 0.15 & 0.12 & -0.27 & 0.3 & & & \\
\hline 14 & CORRUPTION & 0.22 & 0.06 & 0.02 & 0.07 & 0.06 & 0.19 & 0 & 0.01 & -0.08 & 0.16 & 0.37 & 0.37 & -0.21 & & \\
\hline 15 & CAPITALIZATION & -0.1 & -0.1 & 0.06 & 0.01 & -0.02 & -0.02 & -0.07 & 0.15 & 0.15 & 0.16 & 0.14 & -0.07 & -0.03 & 0.38 & \\
\hline 16 & US_COTATION & 0.03 & 0 & 0.03 & 0 & -0.03 & 0.01 & 0.02 & -0.02 & 0.1 & -0.03 & -0.01 & 0.02 & 0.11 & -0.02 & -0.01 \\
\hline
\end{tabular}

The above variables are defined as in Table 5.2.

\section{Results and Analyses}

In this section, we test whether the mean of the dependent variables (cost of capital, quality of 
accounting income, and rating) is statistically identical for the periods before and after mandatory adoption of IFRS.

Table 4 shows a lower average cost of capital after adoption of IFRS, going from $9.04 \%$ to $6.34 \%$. We perform a mean comparison test (Student's t) to determine whether this difference is statistically significant. This difference of $2.70 \%$ is associated with a $p$-value of 0.081 . Thus, we reject the null hypothesis and conclude that mandatory adoption of IFRS has a statistically significant impact on cost of capital. Preparers of financial information therefore benefit from the mandatory adoption of IFRS. In a recent study, Li (2010) poses the question of whether adoption of IFRS by European firms has reduced their cost of equity (cost of equity capital). Based on a sample of 1,084 European firms for the period 1995 to 2006, this author concludes that one observes, on average, a statistically significant decrease in the cost of equity of 47 basis points. Our results point in the same direction, while finding a more pronounced difference (270 basis points).

Table 4. Difference in Cost of Capital before and after Adoption of Mandatory IFRS

\begin{tabular}{lrrrrrr}
\hline Group & \multicolumn{1}{c}{ N } & Mean & Standard error & Standard deviation & Confidence interval (95\%) \\
\hline Before IFRS adoption & 190 & 9.04 & 1.22 & 17.40 & 4.82 & 13.63 \\
After IFRS adoption & 91 & 6.34 & 1.08 & 12.80 & 2.39 & 10.21 \\
Overall & 281 & 8.11 & 0.90 & 15.97 & 4.58 & 11.64 \\
Difference & & 2.70 & 1.91 & & -1.08 & 6.48 \\
& & & & $\mathrm{t}=1.405$ \\
& & & & \\
& Degrees of freedom $=279$ & & &
\end{tabular}

${ }^{*} p<0.10,{ }^{* *} p<0.05,{ }^{* * *} p<0.01$

Table 5 shows no significant difference of the quality of accounting income for investors ( $p$-value of 0.564). Our results do not go in the same direction as those of (Brüggemann, Daske, Homburg, and Pope, 2011), who analyze the response of individual investors after mandatory adoption of IFRS. Based on a sample of 4,869 firms listed on the German stock exchange in Frankfurt, these authors conclude that mandatory adoption of IFRS increases foreign investment, not only for professional investors as suggested in the literature, but also for individual investors. 
Table 5. Difference in Quality of Accounting Income before and after Mandatory Adoption of IFRS

\begin{tabular}{llllllc}
\hline Group & $\mathrm{N}$ & Mean & Standard error & Standard deviation & \multicolumn{2}{l}{ Confidence interval (95\%) } \\
\hline Before IFRS adoption & 8242 & 2230.70 & 565.21 & 51313.17 & 1122.74 & 3338.66 \\
After IFRS adoption & 5144 & 2379.67 & 738.19 & 52943.89 & 932.51 & 3826.82 \\
Overall & 13386 & 2287.94 & 448.96 & 51943.96 & 1407.91 & 3167.97 \\
Difference & & -148.97 & 923.02 & & -1958.21 & 1660.27 \\
& & & & & & $\mathrm{t}=-0.161$ \\
\hline
\end{tabular}

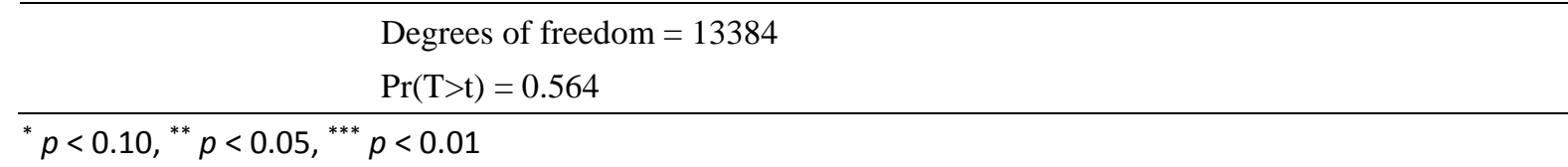

For creditors, the dependent variable is measured by the firm's credit rating (RATING). For this variable, we note that in categories 1 and 2 there is an improvement in credit rating when comparing the first period before mandatory adoption. According to the credit ratings agencies, there are six categories of credit ratings, ranked from 1 to 6 . Table 6 shows that the change in credit rating is associated with a $p$-value of 0.000 , less than 0.05 . Because the dependent variable is a categorical one, we use the Mann-Whitney test for performing comparisons between the two periods for the third empirical model, we conclude that the mandatory transition to IFRS has a favorable impact on benefits to creditors, if credit is used as a measure.

Table 6. Difference in Credit Rating before and after IFRS Mandatory Adoption

\begin{tabular}{lrrrr}
\hline Group & N & Total of ranks & Expected sum & \\
\hline Before IFRS adoption & 6208 & 33829413 & 32849632 & \\
After IFRS adoption & 4374 & 22165241 & 23145021 & \\
Combined & 10582 & 55994653 & 55994653 & \\
\hline Standard deviation & & & 2150167 \\
Z-Mann-Whitney & & & 6.524 \\
Prob. $>\mathrm{z}$ & & & $0.000^{* * *}$ \\
\hline D.10, $^{* *} p<0.05,{ }^{* * *} p<0.01$ & & & &
\end{tabular}

Our results go in the same direction as those of (Wu and Zhang,2009), but only in the context of voluntary adoption of IFRS.

\subsection{Analysis of Results of the Hypothesis of Information Asymmetry (H2)}

Results for our empirical tests of $\mathrm{H} 2, \mathrm{H} 3$ and $\mathrm{H} 4$ are presented in Table 7. Before performing our statistical tests, we have standardized all the interaction variables.

The statistical test of $\mathrm{H} 2$ fails to capture a possible correlation between cost of capital and mandatory adoption of IFRS in the case of firms with strong information asymmetry ( $p$-value 
of 0.482 ). In our predictions, the expected sign of the coefficient of the interaction IFRS*ASYM should be negative and significant. Our results do not point in that direction. This difference in the behavior of the interaction variable may be explained by the fact that the time horizon of three years (2005-2007) is too small to capture the impact of mandatory adoption of IFRS for firms with high information asymmetry.

For investors, our results do not support the second hypothesis regarding the correlation between quality of accounting income and the mandatory adoption of IFRS in firms with high information asymmetry ( $p$-value of 0.441 ). In the accounting literature, some authors are of the opinion that adoption of IFRS alone does not reduce firm information asymmetry. For example, Dumontier and Baalbaki (2012) suggest that, while in Europe mandatory adoption of IFRS resulted in a decrease in asymmetric information, this occurred at the same time as adoption of the directive on market transparency (Market Abuse Directive). Thus, the results of this study suggest that reducing information asymmetry attributed to adoption of IFRS is in fact heavily influenced by the adoption of the Market Abuse Directive.

Table 7. Results of Regressions

\begin{tabular}{|c|c|c|c|c|c|c|c|c|c|}
\hline \multirow{3}{*}{$\begin{array}{l}\text { Dependent } \\
\text { variable }\end{array}$} & \multicolumn{3}{|c|}{$\begin{array}{l}\text { Model } 1 \text { for preparers of financial } \\
\text { information }\end{array}$} & \multicolumn{3}{|c|}{ Model 2 for investors } & \multicolumn{3}{|c|}{ Model 3 for creditors } \\
\hline & \multicolumn{3}{|c|}{ Cost of capital } & \multicolumn{3}{|c|}{ Earnings quality } & \multicolumn{3}{|l|}{ Credit risk } \\
\hline & Beta coefficient & $\mathrm{t}$ & $p$-value & Beta coefficient & $\mathrm{t}$ & $p$-value & Beta coefficient & $\mathrm{t}$ & $p$-value \\
\hline Constant & 15.906 & 0.95 & 0.343 & -302.111 & -0.09 & 0.931 & 12.987 & 4.76 & 0.000 \\
\hline IFRS & -1.768 & -0.68 & 0.496 & -612.069 & -1.28 & 0.202 & 0.229 & 1.01 & 0.313 \\
\hline ASYM & -2.513 & -2.61 & $0.010^{* *}$ & 186.675 & 1.10 & 0.269 & -0.540 & -7.51 & $0.000^{* * *}$ \\
\hline FIN_DEPEND & 0.103 & 0.49 & 0.628 & 0.469 & 0.33 & 0.742 & 0.002 & 3.75 & $0.000^{* * *}$ \\
\hline FAMILY & -1.415 & -0.60 & 0.547 & 12.819 & 0.03 & 0.974 & -0.978 & -5.23 & $0.000 * * *$ \\
\hline IFRS*ASYM & 0.696 & 0.71 & 0.482 & 184.716 & 0.77 & 0.441 & -0.243 & -2.13 & $0.033 * *$ \\
\hline IFRS*FIN_DEPEND & -0.002 & -0.01 & 0.993 & -0.252 & -0.04 & 0.970 & 0.033 & 6.66 & $0.000 * * *$ \\
\hline IFRS*FAMILY & 0.125 & 0.03 & 0.947 & -80.372 & -0.13 & 0.895 & -0.188 & -0.66 & 0.508 \\
\hline CAPITALIZATION & 0.933 & 1.67 & 0.097 & 454.334 & 0.74 & 0.458 & -0.225 & -7.74 & $0.000 * * *$ \\
\hline CORRUPTION & -1.269 & -0.47 & 0.637 & -355.907 & -0.82 & 0.412 & $0.000^{* * *}$ & $0.00^{* * *}$ & 0.990 \\
\hline PROTECTION & 11010.15 & 10.03 & $0.000 * * *$ & 20847.35 & 4.61 & $0.000^{* * *}$ & -0.262 & -0.55 & 0.584 \\
\hline SEPARATION & 2.183 & 0.82 & 0.414 & 242.399 & 3.82 & $0.000 * * *$ & -0.783 & -3.60 & $0.000 * * *$ \\
\hline TAXATION & 2.153 & 0.16 & 0.872 & 7006.926 & 2.47 & $0.014 * *$ & -1.476 & -4.29 & $0.000 * * *$ \\
\hline US_COTATION & 4026.81 & 2.24 & $0.025 * *$ & 2822.516 & 1.56 & 0.119 & 0.678 & 0.80 & 0.425 \\
\hline COUNTRY & Incl. & Incl. & Incl. & Incl. & Incl. & Incl. & Incl. & Incl. & Incl. \\
\hline INDUSTRY & Incl. & Incl. & Incl. & Incl. & Incl. & Incl. & Incl. & Incl. & Incl. \\
\hline $\mathrm{R}^{2}$ adjusted & 0.35 & & & 0.09 & & & 0.11 & & \\
\hline $\mathrm{N}$ & 281 & & & 13386 & & & 10528 & & \\
\hline VIF & 1.97 & & & 1.97 & & & 1.97 & & \\
\hline
\end{tabular}

In the case of creditors, results suggests that the mandatory adoption of IFRS tend to increase information asymmetry, since the coefficient of the variable IFRS*ASYM is negative. 


\subsection{Analysis of Results from the Assumption of Financial Dependence (H3)}

For firms, our results do not support the H3, that there is a correlation between mandatory adoption of IFRS and cost of capital for firms with high financial dependence ( $p$-value of 0.993). These results do not point in the same direction as our predictions, since the negative sign of the interaction coefficient ASYM * FIN_DEPEND is contrary to expectation.

For investors, the results do not support $\mathrm{H} 3$ regarding the correlation between quality of accounting income and mandatory adoption of IFRS in firms with high financial dependence ( $p$-value of 0.970). The expected behavior of the interaction IFRS * FIN_DEPEND is not concretized. Firms with high financial dependence, as identified by (Rajan and Zingales, 1998), include those in high-technology sectors. By analyzing only this kind of firm domiciled in Germany, Lin (2012) finds that when switching from U.S. GAAP to IFRS, the quality of financial reporting decreases. Mandatory adoption of IFRS would be far better in providing information when measurement includes performance management. Thus, this conclusion is similar to our own regarding preparers of financial information and investors.

Finally, in the third specific model for creditors, the results support H3 regarding the correlation between the proxy of the benefit to creditors, credit rating, and mandatory adoption of IFRS in firms with high financial dependence ( $p$-value of 0.000). Indeed, the positive coefficient on the interaction IFRS * FIN_DEPEND in the direction of creditors is in line with our expectations.

\subsection{Analysis of Results for the Hypothesis of Family Ownership Structure (H4)}

When we analyze the combined effect of ownership structure and adoption of IFRS, we find no relation to cost of capital ( $p$-value of 0.947).

For investors, these results suggest that there is no correlation between quality of accounting income and the interaction between mandatory adoption of IFRS and ownership structure ( $p$-value of 0.895). Ben Ali, Trabelsi and Summa (2008) analyze the relationship between quality of disclosure and ownership structure based on a sample of French firms. These authors conclude that in family businesses, disclosure is of low quality. However, there is no evidence to infer that improvement in the quality of the information, including adoption of accounting standards such as IFRS, would have a positive or negative impact on the various stakeholders in the process of financial reporting. In our case, the empirical model indicates no economic benefit from mandatory adoption of IFRS for family businesses. Our empirical model fails to capture any economic impact of mandatory IFRS adoption in firms with family ownership structure.

The same conclusion is valid for creditors ( $p$-value of 0.508 ); thus $\mathrm{H} 4$ is rejected for that category of users of financial information.

\section{Conclusion}

This article analyzes the consequences of mandatory adoption of IFRS for a study period of 
six years, 2002 to 2007. Given the speed at which IFRS became mandatory throughout the world, it is important to examine one of the least explored aspects of this issue, namely the economic value of financial transparency for preparers of financial information and investors.

We analyze the effect of mandatory IFRS adoption on cost of capital and earnings quality. We test four hypotheses related to economic benefits for preparers of financial information reported under IFRS. Our findings suggest that mandatory adoption of IFRS brings economic benefits to preparers of financial information, but not to investors. In line with the accounting literature focusing on the economic consequences of mandatory IFRS adoption around the world, our research sheds new light on at least two aspects of this issue. On a theoretical level, our perspective of positive accounting theory enables us to understand the role of lobbying in mandatory adoption of IFRS around the world. At a practical level, our research provides some answers to global standards-setters in terms of the concerns expressed in the 2010 conceptual framework.

\section{References}

Ali A., C. Tai-Yuan \& R. Suresh. (2007). Corporate Disclosures by Family Firms. Journal of $\begin{array}{llll}\text { Accounting } \quad \text { and 238-286. } & \text { 44(1-2), }\end{array}$ https://doi.org/10.1016/j.jacceco.2007.01.006

Ali, A. et L-S. Hwang. (2000). Country-Specific Factors Related to Financial Reporting and Value Relevance of Accounting Data. Journal of Accounting Research, 38(1), 1-21. https://doi.org/10.2307/2672920

Ashbaugh, H. (2001). Non-US Firms'Accounting Standards Choices. Journal of Accounting and Public Policy, 20(2), 129-153. https://doi.org/10.1016/S0278-4254(01)00025-4

Ashbaugh, H., \& M. Pincus. (2001). Domestic Accounting Standards, International Accounting Standards and the Predictability of Earnings. Journal of Accounting and Research, 39(3), 417-434. https://doi.org/10.1111/1475-679X.00020

Atwood, T. J., M. S. Drake, J. N. Myers \& L. A. Myers. (2011). Do Earnings Reported under IFRS Tell Us More about Future Earnings and Cash Flows? Journal of Accounting and Public Policy, 30(2), 103-121. https://doi.org/10.1016/j.jaccpubpol.2010.10.001

Ball, R., \& P. Brown. (1968). An Empirical Evaluation of Accounting Income Numbers. Journal of Accounting Research, 6(2), 159-178. https://doi.org/10.2307/2490232

Ball, R. (2001). Infrastructure Requirements for an Economically Efficient System of Public Financial Reporting and Disclosure. In Litan,R. et R. Herring (Eds.), Brooking Wharton Papers on Financial Services, Brookings Institution Press, Washington, DC, p.127-182. https://doi.org/10.1353/pfs.2001.0002

Ball, R., A. Robin \& J. S. Wu. (2003). Incentives versus Standards: Properties of Accounting Income in Four East Asian Countries. Journal of Accounting and Economics, 36(1-3), 
235-270. https://doi.org/10.1016/j.jacceco.2003.10.003

Ball, R., A. Robin \& G. Sadka. (2008). Is Financial Reporting Shaped by Equity Markets or by Debts Markets? An International Study of Timeliness and Conservatism. Review of Accounting Studies, 13(2-3), 168-205. https://doi.org/10.1007/s11142-007-9064-x

Barth, M. E., W. R. Landsman \& M. H. Lang. (2008). International Accounting Standards and Accounting Quality. Journal of Accounting Research, 46(3), 467-498. https://doi.org/10.1111/j.1475-679X.2008.00287.x

Barth, M. E., \& K. Schipper. (2008). Financial Reporting Transparency. Journal of Accounting, Auditing and Finance, 23(2), 173-190. https://doi.org/10.1177/0148558X0802300203

Barth, M. E., Y. Konchitechki \& W. R. Landsman. (2011). Cost of Capital and Earnings Transparency. Journal of Accounting and Economics, 55(2-3), 206-224. https://doi.org/10.1177/0148558X0802300203

Beaver, W. H. (1968). The Information Content of Annual Earnings Announcements. Journal of Accounting Research, 6, 67-92. https://doi.org/10.2307/2490070

Ben Ali, C., S. Trabelsi \& M. Summa. (2008). Disclosure Quality and Ownership Structure: Evidence from the French Stock Market. Corporate Ownership and Control, 5(2), 1-37.

Beneish, M. D., B. P. Miller \& T. L. Yohn. (2010). "IFRS Adoption and Cross-Border Investment in Equity and Debt Markets." Working Paper, Indiana University

Beuselinck, C., P. Joos, I. K. Khurana \& S. Van der Meulen. (2010). "Mandatory IFRS Reporting and Stock Price Informativeness." Working Paper no. 2010-82, Catholic University of Lille

Botosan, C. A., \& M. A. Plumlee. (2002). A Re-examination of Disclosure Level and the Expected Cost of Equity Capital. Journal of Accounting Research, 40(1), 21-40. https://doi.org/10.1111/1475-679X.00037

Brüggemann, U., H. Daske, C. Homburg \& p. F. Pope. (2011). How do Individual Investors React to Global IFRS Adoption? Working Paper, Humboldt University of Berlin.

Casta, J. F. (2009). Théorie Positive de la Comptabilité. In Encyclopédie de la Comptabilité, Contrôle de Gestion et Audit, sous la direction de B. Colasse (Ed. Economica), Paris, p. 1393-1402.

Charreaux, G., \& P. Desbrières. (1998). Gouvernance des Entreprises: Valeur Partenariale contre Valeur Actionnariale. Finance Contrôle Stratégie, 1(2), 57-88.

Claessens, S., S. Djankov, J. Fan et L.H.P.Lang. (2002). Disentangling the Incentive and Entrenchment Effects of Large Shareholdings. Journal of Finance, 57(6), 2741-2771. https://doi.org/10.1111/1540-6261.00511

Collins, D. W., S. P. Kothari, J. Shanken \& R. Sloan. (1994). Lack of Timeliness and Noise 
as Explanations for the Low Contemporaneous Return-Earnings Association. Journal of $\begin{array}{lll}\text { Accounting and } & \text { Economics, }\end{array}$ https://doi.org/10.1016/0165-4101(94)90024-8

Cuijpers, R., \& W. Buijink. (2005). Voluntary Adoption of Non-local GAAP in the European Union: A Study of Determinants and Consequences. European Accounting Review, 14(3), 487-524. https://doi.org/10.1080/0963818042000337132

Daske, H. (2006). Economic Benefits of Adopting IFRS or US-GAAP. Have the Expected Costs of Equity Capital Really Decreased? Journal of Business Finance and Accounting, 33(3\&4), 329-373. https://doi.org/10.1111/j.1468-5957.2006.00611.x

Daske, H., L. Hail, C. Leuz \& R. Verdi. (2008). Mandatory IFRS Reporting Around the World: Early Evidence on the Economic Consequences. Journal of Accounting Research, 46(6), 1085-1142. https://doi.org/10.1111/j.1475-679x.2008.00306.x

Daske, H., L. Hail, C. Leuz \& R. Verdi. (2012). Adopting a Label: Heterogeneity in the Economic Consequences of the IFRS Adoptions. Working Paper Goethe University of Frankfurt

Diamond, D. et R. Verrechia. (1991). Disclosure, Liquidity and the Cost of Capital. Journal of Finance, 64(4), 1325-1359. https://doi.org/10.1111/j.1540-6261.1991.tb04620.x

Disle, C., \& C. Noël. (2007). La Révolution des Normes IFRS: Convergence de la Comptabilité vers la Finance? La Revue des Sciences de Gestion: Direction and Gestion, 224-225, 17-27. https://doi.org/10.3917/rsg.224.0017

Dumontier, P., \& F. Baalbaki. (2012). "Disentangling the Joint Effects of IFRS and MAD on Asymmetry in EU Capital Markets.” Working Paper, University of Grenoble.

Fan, J. P. H., \& T. J. Wong. (2002). Corporate Ownership Structure and the Informativeness of Accounting Earnings in East Asia. Journal of Accounting and Economics, 33(3), 401-425. https://doi.org/10.1016/S0165-4101(02)00047-2

Florou, A., \& P. F. Pope. (2012). Mandatory IFRS Adoption and Institutional Investment Decisions. The Accounting Review, 87(6), 1993-2025. https://doi.org/10.2308/accr-50225

Francis, J. R., I. K. Khurana \& R. Pereira. (2005). Disclosure Incentives and Effects on Cost of Capital around the World. The Accounting Review, 80(4), 1125-1140. https://doi.org/10.2308/accr.2005.80.4.1125

Gao, P. (2010). Disclosure Quality, Cost of capital, and Investor Welfare. The Accounting Review, 85(1) 1-28. https://doi.org/10.2308/accr.2010.85.1.1

Gordon, M. J. (1964). Postulates, Principles and Research in Accounting. The Accounting Review, 39(2), 251-263.

Guay, W. R., S. P. Kothari \& S. Shu. (2011). Properties of Implied Cost of Capital Using 
Analysts' Forecasts. Australian Journal of Management, 36(2), 125-149. https://doi.org/10.1177/0312896211408624

Habib, A. (2006). Information Risk and the Cost of Capital: Review of the Empirical Literature. Journal of Accounting Literature, 25, 127-168.

Hope, O.-K., J. Jin \& T. Kang. (2006). Empirical Evidence on Jurisdictions that Adopt IFRS. Journal of International Accounting Research, 5(2), 1-20. https://doi.org/10.2308/jiar.2006.5.2.1

Iatridis, G. (2010). International Financial Reporting Standards and the Quality of Financial Statement Information. International Review of Financial Analysis, 19(3), 193-204. https://doi.org/10.1016/j.irfa.2010.02.004

International Accounting Standards Board (IASB) and Financial Accounting Standard Board (FASB). (2010). "Conceptual Framework for Financial Reporting. Phase A: Objective and Qualitative Characteristics, p38.

Ivashima, V. (2009). Asymmetric Information Effects on Loan Spreads. Journal of Financial Economics, 92(2), 300-319. https://doi.org/10.1016/j.jfineco.2008.06.003

Kim, J.-B.., \& H. Shi. (2007). Enhanced Disclosures via IFRS and Stock Price Synchronicity Around the World: Do Analyst Following and Institutional Infrastructure Matter? Working Paper, Hong Kong Polytechnic University

Kim, J.-B., J. S. L. Tsui \& C. H. Yi. (2011). The Voluntary Adoption of International Financial Reporting Standards and Loan Contracting Around the World. Review of Accounting Studies, 16(4), 779-811. https://doi.org/10.1007/s11142-011-9148-5

King, M.R et E. Santor. (2007). Family Values: Ownership Structure, Performance and Capital Structure of Canadian Firms. Bank of Canada Working Paper 2007-40, p.1-39.

Korczak, A., \& P. Korczak. (2009). Corporate Ownership and the Information Content of Earnings in Poland. Applied Financial Economics, 19(9), 703-717. https://doi.org/10.1080/09603100802167247

Kosi, U., P. F. Pope \& A. Florou. (2012). Does IFRS Adoption Improve Credit Relevance of Accounting Information? Working Paper King's College London

La Porta, R., F. Lopez-de-Silanes, A. Shleifer \& R. Vishny. (1998). Law and Finance. Journal of Political Economy, 106(6), 1113-1155. https://doi.org/10.1086/250042

Leuz, C. (2003). IAS versus US GAAP: Information Asymmetry-Based Evidence from Germany's New Market. Journal of Accounting Research, 41(3), 445-472. https://doi.org/10.1111/j.1475-679X.2003.00111.x

Li, S. (2010). Does Mandatory Adoption of International Financial Reporting Standards in European Union Reduce the Cost of Equity Capital? The Accounting Review, 85(2), 607-636. https://doi.org/10.2308/accr.2010.85.2.607 
Lin, S. (2012). "Does Accounting Quality Change Following a Switch from US GAAP to IFRS? Evidence from Germany.” Working Paper, Florida International University

Liu, C., L. J. Yao, N. Hu \& L. Liu. (2011). The Impact of IFRS on Accounting Quality in a Regulated Market: An Empirical Study of China. Journal of Accounting, Auditing \& Finance, 26(4), 659-676. https://doi.org/10.1177/0148558X11409164

Peek, E., R. Cuijpers \& W. Bwijink. (2009). Creditors' and Shareholders' Reporting Demands in Public versus Private Firms: Evidence from Europe. Contemporary Accounting Research, 2(1), 49-91.

Rajan, R. G., \& L. Zingales. (1998). Financial Dependence and Growth. The American Economic Review, 88(3), 559-586.

Tang, T. T. (2009). Information Asymmetry and Firm Credit Market Access: Evidence from Moody's Credit Rating Format Refinement. Journal of Financial Economics, 93(2), 325-351. https://doi.org/10.1016/j.jfineco.2008.07.007

Tendeloo, B. V., \& A. Vanstraelen. (2005). Earnings Management under German GAAP versus IFRS. European Accounting Review, 14(1), 155-180. https://doi.org/10.1080/0963818042000338988

Tucker J. W., \& P. A. Zarowin. (2006). Does Income Smoothing Improve Earnings Informativeness? The Accounting Review, 81(1), 251-270. https://doi.org/10.2308/accr.2006.81.1.251

Watts, R. L., \& J. L. Zimmerman. (1986).“Positive Accounting Theory. Englewood Cliffs, NJ: Prentice-Hall 388 p.

Wu, J. S., \& I. X. Zhang. (2009). The Adoption of Internationally Recognized Accounting Standards: Implications for the Credit Markets. Working Paper, University of Rochester

Zhao, R., \& B. Millet-Reyes. (2007). Ownership Structure and Accounting Information Content: Evidence from France. Journal of International Financial Management and Accounting, 18(3), 223-246. https://doi.org/10.1111/j.1467-646X.2007.01013.x

\section{Copyright Disclaimer}

Copyright for this article is retained by the author(s), with first publication rights granted to the journal.

This is an open-access article distributed under the terms and conditions of the Creative Commons Attribution license (http://creativecommons.org/licenses/by/3.0/). 